\title{
«Alga todo y espumas» (Góngora, Soledades, 1613, v. 26) «Alga todo y espumas» (Góngora, Soledades, 1613, I. 26)
}

\section{Rafael Bonilla Cerezo}

orcid.org/0000-0002-2851-0630

Universidad de Córdoba

ESPAÑA

Ih1bocer@uco.es

[Hipogrifo, (issn: 2328-1308), 7.2, 2019, pp. 657-686]

Recibido: 11-01-2019 / Aceptado: 18-03-2019

DOI: http://dx.doi.org/10.13035/H.2019.07.02.48

Resumen. El paréntesis «(alga todo y espumas)» de la Soledad primera (v. 26) de Góngora no ha logrado despojarse aún de la etiqueta de locus oscuro que se le viene asignando desde los tiempos de Pellicer (Lecciones solemnes, 1630). El presente artículo pasa revista a las opiniones críticas al respecto y sugiere una nueva tesis a la luz de cuatro fuentes espigadas de la poesía de Catulo (carmen 64), Ovidio (Metamorfosis, XI, vv. 410-748), Ariosto (Orlando furioso, cantos X-XI) y Luis de Camoens (el soneto «Como quando o mar tempestuoso»).

Palabras clave. Góngora; Soledades; Catulo; Ovidio; Ariosto.

Abstract. The parenthesis «(alga todo y espumas)» of the Soledad primera (I. 26) of Góngora has not yet shed the label of locus oscurus that has been assigned to it since the age of Pellicer (Lecciones solemnes, 1630). This article reviews the critical opinions on this subject and suggests a new reading in light of four sources of the poetry of Catullus (Carmen 64), Ovid (Metamorphosis, XI, I. 410-748), Ariosto (Orlando furioso, chapters $\mathrm{X}-\mathrm{XI}$ ) and Luis de Camoens (the sonnet «Como quando o mar tempestuoso»).

Keywords. Góngora; Soledades; Catulo; Ovidio; Ariosto. 


\section{LOS ENIGMAS DE LA ESFINGE}

Mientras los agudos Laureano, Ronsardo, Florindo y Silverio discurrían en El Pusílipo (1629) de Suárez de Figueroa acerca de un cuaderno de poesías gongorinas, Silverio, el más perspicuo de estos cuatro sujetos, se permite matizar que todas las obras del «moderno Marcial» ${ }^{1}$ consistieron en una «variedad de fragmentos que, aunque son pedazos de oro, es lástima que no se haya aplicado ingenio tan superior a una larga y proseguida que, sin duda, fuera un cielo todo grabado de joyas»². Acaso desentone aquí la inclusión del Polifemo (1612) y las Soledades $(1613-1614)^{3}$ - de veras «largos y proseguidos»-, pero lo cierto es que todavía se antoja imprescindible volver a los antiguos y modernos comentaristas de los «poemas mayores» de don Luis, «por repelentes que sean, o parezcan ser, si queremos entender plenamente [sus versos] $»^{4}$.

Así las cosas, en la tarea de despejar algún nubarrón que otro - «enigmas de la esfinge», según feliz imagen de Pellicer ${ }^{5}-$ brilla con luz propia la edición de las Soledades que Robert Jammes publicó en la editorial Castalia a finales del último siglo (1994). No en vano, plumas más autorizadas que la mía, como las del añorado Antonio Alatorre y su tocayo y no menos erudito Antonio Carreira, apenas tardaron en saltar a la arena, prestos a aplaudir sus méritos con calidez y justeza ${ }^{6}$.

Eso sí, tales elogios no le estorbarían al maestro Alatorre, esta vez en un artículo-reseña de los Gongoremas y de la edición de los Romances del genio cordobés que firmó Carreira ${ }^{7}$, a la hora de concluir que «a los dos [y habla de su concienzudo amigo] nos irritan las ediciones hechas a la diabla, con malas notas y mala puntuación del texto. Los dos ponemos muy en alto la edición de las Soledades [del profesor] Jammes, y también los dos le hacemos algún que otro reparo»8. De ahí que también yo -como furgón de cola- procure revelar en las páginas que siguen una dificultad vencible de la Soledad I: el paréntesis «(alga todo y espumas)» (v. 26), solo en parte aclarado por el hispanista galo; y lo hago no tanto «a la diabla» como en hábito de curioso diablillo?.

1. Blanco (2013, pp. 44-46) ha estudiado cómo las décimas de Góngora «ensayan una vena epigramática voluntariamente cercana a la de [Marcial] que, aun más que Meleagro, que Calímaco o que Catulo, dio a este género menor sus letras de nobleza y dejó en él una impronta inconfundible». Los corchetes son míos.

2. Suárez de Figueroa, Pusílipo. Ratos de conversación en los que dura en paseo, p. 260.

3. Cito siempre por la edición de las Soledades en el haber de Jammes (1994).

4. Romanos, 2002, p. 201.

5. Pellicer, Lecciones solemnes, p. 171

6. Ver Alatorre, 1996; y Carreira, 1998.

7. Carreira, 1998 y Góngora, Romances, ed. Carreira.

8. Alatorre, 2000, p. 304.

9. Continúa vigente, tres cuartos de siglo después de que la formulara, esta premisa de Spitzer (1980, p. 257) a propósito de la segunda edición de las Soledades publicada por Dámaso Alonso en Cruz y raya (1936): «En esta labor de ahondamiento y depuración en la interpretación de Góngora le hemos 


\section{EL ESCOLLO CORONADO}

A resultas del naufragio de su peregrino, Góngora señala al comienzo de la Soledad I (p. 202) que

Del Ocëano pues antes sorbido, y luego vomitado

no lejos de un escollo coronado

de secos juncos, de calientes plumas,

(alga todo y espumas)

halló hospitalidad donde halló nido

de Júpiter el ave (vv. 22-28).

Y Jammes se esfuerza en glosarlo:

«alga todo y espumas» se refiere al peregrino según Pellicer, interpretación adoptada por D. Alonso, y que parece la más verosímil; pero Salcedo, en su afán de contradecir a Pellicer, la rechaza con cierta ironía: «No admira don Luis que hallase hospedaje quien salía tan mal tratado y horrible de las aguas, sino describe el modo cómo salía, habiéndole arrojado el mar cerca de un escollo, que, por batirle sus ondas con la tempestad, estaría lleno de espumas y de algas». Para apoyar su interpretación, Salcedo cita una comparación de Virgilio (Eneida, VII, vv. 587590) en la que, en efecto, se evocan escollos cubiertos de espuma y algas ${ }^{10}$; pero la imitación no es evidente, y sería contradictorio decir que el escollo es «todo» alga y espumas, cuando se acaban de evocar los «secos juncos» y las «calientes plumas» que lo coronan. Fundándose en otro argumento, Carreira llega a una conclusión semejante: «Aunque este verso puede referirse al escollo, debe de ser recuerdo de la costra salina que cubre a Ulises cuando arriba, náufrago, a la tierra de los feacios (Odisea, VI, 137, 219 y 225)» ${ }^{11}$.

Acabo de razonar junto a Tanganelli que no termina de convencernos la lección de García Salcedo Coronel («[Góngora] describe el modo cómo salía [el peregrino], habiéndole arrojado el mar cerca de un escollo [...] lleno de espumas y de algas»), porque si bien abundan los ecos virgilianos en las Soledades ${ }^{12}$, en este pasaje la cita del autor de la Eneida resulta un poco traída por los pelos ${ }^{13}$. Cuando se trata de describir la imagen del bello náufrago, apostaría con mayor seguridad por los tres episodios que Sinicropi, y luego Carreira, espigaron del libro VI de La Odisea

acompañado [a Alonso], tanto personalmente yo como mis alumnos de la Universidad Johns Hopkins, a fin de contribuir a la menor resolución de las "dificultades vencibles" y a la posible reducción del número de las "invencibles"».

10. Juzgo pertinente su transcripción: «Virgilio, en el libro VII de su Eneida, nos ofrece un lugar con que se declara bien este pensamiento de don Luis: "Ut pelagi rupes magno veniente fragore / qua sese multis circum latrantibus undis, / mole tenet scopuli ne quidquam et spumea circum / saxa fremunt, laterique illisa / refunditur alga"» (Salcedo Coronel, «Soledades» de don Luis de Góngora comentadas, p. 21).

11. Jammes, en su ed. de Soledades, pp. 202-204.

12. Blecua, 2008.

13. Bonilla Cerezo y Tanganelli, 2016, p. 239. 
(vv. 137-138, 219-220, 225-226) ${ }^{14}$. Por la sencilla razón, aunque Homero no aludiera a las algas, sino solo a la costra de sal que revestía a Ulises, de que ayudan a iluminar los versos que nos ocupan.

También creo que convendría releer el libro $V$ de la epopeya griega: en concreto aquella secuencia en que la balsa del rey de Ítaca es zarandeada hacia unos escollos y el héroe, aferrado a una roca, da gracias a Zeus por consentirle que vuelva a pisar tierra firme (vv. 400-435) ${ }^{15}$. Incluso me permito añadir como fuente gongorina el desembarco de Eneas en Cartago tras su naufragio (Eneida, I, vv. 170-173): «huc septem Aeneas collectis nauibus omni / ex numero subit, ac magno telluris amore / eggresi optata potiuntur Troës harena / et sale tabentis artus in litore ponunt» («Aquí, con las siete naves que reuniera de todo su grupo, / Eneas penetra, con gran ansia de tierra. / Desembarcando los troyanos ganan la deseada arena / y recuestan en la playa sus miembros empapados de sal») ${ }^{16}$.

Quizá sean estos y no otros, en efecto, los modelos que copió el discretísimo personaje de las Soledades; sobre todo cuando Góngora nos dice que, abrazado a una «breve tabla» (v. 18), su peregrino se aproxima a un escollo dominado por un águila, el primero de la pulida serie de signos jupiterinos que don Luis diseminó por la Dedicatoria («Pasos de un peregrino son errante») y el íncipit de sus silvas.

De este modo, el arranque de la Soledad I ratificaría sus deudas con el poema de Homero, aunque Góngora no lo haya confesado de forma explícita ${ }^{17}$. Y a su zaga con el de Virgilio, aunque el pasaje imitado no sea el que apuntara Salcedo Coronel. No en balde, estoy persuadido de que esta es la razón - su espíritu elusivo a la hora de acopiar fuentes- por la que Cancelliere leyó el paréntesis en cuestión («alga todo y espumas») como una original parodia del nacimiento de Venus ${ }^{18}$. Asimismo, Tanganelli y quien suscribe avenimos con la tesis de Beverley ${ }^{19}$, y más aún con la de Von Prellwitz, para quien el delfín, las plumas y las espumas asoman en las Soleda-

14. Sinicropi, 1976, pp. 126-129; Góngora, Antología poética, ed. Carreira, 1986, p. 204; Góngora, Antología poética, ed. Carreira, 2009, p. 414.

15. El anónimo de Antequera también opina que las «algas» y la «espuma» se refieren al náufrago: «quiere decir que el peregrino salió del mar mojado, de manera que todo él era espumas y ovas, porque, como había escapado en una tabla, la tormenta le dejó tal que más parecía espumas que hombre» (Osuna Cabezas, 2009, p. 184). Nótese la simetría de este pasaje - «paradigma» lo llamarían Enrica Cancelliere y Mercedes Blanco- con otro de la Soledad II, que, sin embargo, no revoca los problemas de los vv. 22-28 de la Soledad de los campos: «vieras intempestivos algún día / (entre un vulgo nadante, digno apenas / de escama, cuanto más de nombre) atunes / vomitar ondas y azotar arenas» (II, vv. 414-417) (Góngora, Soledades, ed. Jammes, p. 479).

16. Ver Virgilio, Eneida. Volumen I (Libros I-III), p. 16.

17. Sobre Góngora y Homero, ver Blanco, 2012, pp. 229-260 y 261-298. Según Sinicropi (1976, pp. 128129), «il motivo ulissiaco ritorna con immagini piú chiare nei versi 116-171 della seconda Soledad, nel lamento al mare rivolto dal peregrino e contenente appunto quell'augurio del "segundo naufragio" che dovrebbe finalmente por fine al "destierro". L'augurio viene innestato sulla rimembranza del primo naufragio, [...] nelle angosciose memorie della donna abbandonata e causa dell'esilio, [...] e della sua misteriosa colpa, [...] connessa al lungo vagabondaggio». Me convence algo menos su apuesta por identificar el paréntesis «(alga todo y espumas)» con el v. 403 del canto V de la Odisea, donde «lòs» sugiere, a su juicio, «il contiguo fonologico alga, mancante nel testo greco».

18. Cancelliere, 2010, p. 74.

19. Beverley, en su ed. de Soledades, pp. 76-77. 
des como «tre riferimenti a Venere [...] trasferibili all'arte della poesia, in una sorta di erotismo estetico che caratterizza la poetica di Góngora» ${ }^{20}$.

$Y$ tampoco nos tomamos a la ligera la posibilidad de que ese islote contra el que el océano vomitó al peregrino sea un vago recuerdo de Escila, primero una hermosa ninfa, luego un monstruo marino con torso de mujer y cola de pez, y finalmente, a causa de su metamorfosis, una roca o escollo que atemorizaba a los navegantes en el estrecho canal que compartía con Caribdis, feroz remolino que devoraba todo cuanto hallaba a su paso. Escila figura tanto en La Odisea como, ocho siglos después, en el carmen 64 de Catulo21; sin orillar - nunca mejor dicho- que a la memoria de Góngora quizá pudo acudir un emblema de Alciato relativo al alción, ave que construye su nido sobre las rocas de la playa, si no encima del mar22; o bien la empresa 87, c. 287, de la centuria III de Sebastián de Covarrubias Horozco (1610), aun cuando en los epigramas que explican dichas estampitas no quede ya ni rastro del sustantivo «algas» y sí, por el contrario, de las citadas «espumas».

Insisto en que no se ha penetrado todavía el busilis del inciso gongorino: «(alga todo y espumas)»; al margen, claro está, de sus posibles vínculos con el citado carmen 64 de Catulo. Juan Antonio González Iglesias, uno de los últimos traductores del cantor de Lesbia, fruto -o así quiero intuirlo- de la ambigüedad retórica del poeta veronés, ha vertido a nuestra lengua el v. 73 del Epitalamio de Tetis y Peleo ("quem procul ex alga maestis Minois ocellis») con maneras tan sobrias como reversibles: «De lejos, entre algas, con ojos apenados» ${ }^{23}$.

Junto con la Odisea, la Eneida, el rarísimo Discurso euboico de Dión Crisósto$\mathrm{mo}^{24}$, las travesías de los peregrinos enamorados ${ }^{25}$, la historia de Jonás y la ballena, luego resucitada por san Juan Clímaco en su Escala espiritual26; la Gerusalemme liberata ${ }^{27}$, el diálogo II padre di famiglia de Torquato Tasso ${ }^{28}$ y un puñado de sonetos del propio Góngora en los que se adivinaban ya los rasgos del peregrino de las

20. Góngora, Le solitudini e altre poesie, p. 237.

21. Acaso el modelo directo vuelva a localizarse en la Eneida (libro III, vv. 420-423): «Dextrum Scylla latus, laeuum implacata Charibdys / obsidet, atque imo barathri ter gurgite uastos / sorbet in abruptum fluctus rursusque sub auras / erigit alternos, et sidera uerberat unda» («El lado derecho Escila lo ocupa, el izquierdo Caribdis / nunca saciada, y del fondo del torbellino de su báratro tres veces sorbe / ingentes oleadas al abismo y de nuevo a los aires / alza otras tantas, y azota los astros con agua»). Ver Virgilio, Eneida. Volumen I (Libros I-III), p. 131, sobre todo al cotejar estos versos del mantuano con los que preceden al paréntesis gongorino que nos concierne. Los transcribo de nuevo: «Del Océano, pues, antes sorbido / y luego vomitado / no lejos de un escollo coronado / de secos juncos, de calientes plumas, / (alga todo y espumas)» (vv. 22-26). Pellicer, Lecciones solemnes, p. 370, se acogió a otro pasaje del poeta latino: «Sorbido y luego vomitado. Ambas a dos circunstancias del naufragio pone don Luis ejecutadas en el extranjero: el sorberle, primero; luego el vomitarle. Calidad del mar que hallo en Virgilio, lib. 8. Aeneid., en los bajíos de Ecila y Caribdis: Sorbet in abructum fructus, rursusque sub auras erigit alternos».

22. Bonilla Cerezo y Tanganelli, 2013, pp. 42-43. Bernardino Daza Pinciano tradujo las empresas del humanista lombardo en 1549 (Lyon, Matías Bonhomme).

23. Catulo, Poesías, trad. González Iglesias, p. 343. Cito por esta edición.

24. Lida de Malkiel, 1975, pp. 241-251.

25. Vilanova, 1989; Cruz Casado, 1990; Lara Garrido, 2004; Trambaioli, 2015.

26. Jones, 1954.

27. Ferretti, 2013.

28. Lara Garrido, 2003. 
dos silvas ${ }^{29}$, considero que podría sumarse otra tesela al mosaico de la Soledad I: la sensual imagen de Ariadna, princesa de Creta que, desesperada por la fuga de Teseo, mítico rey de Atenas, lloraba en un paisaje dominado por unas rocas similares a las de las Soledades; unos escollos, en fin, tapizados asimismo por plantas marinas.

Pero nada nos impide colegir que el sintagma «ex alga» del epitalamio de Catulo («quem procul ex alga maestis Minois ocellis») aluda al cuerpo de la hija de Minos y Pasífae: un desnudo - preludio avant la lettre de las exquisitas ninfas de Gustave Moreau, rodeadas de anémonas y corales - bastante más inspirador que la imagen del escollo; al tiempo que lindero con la explicación que Pellicer y Dámaso Alonso dieron de ese turbio paréntesis que es el v. 26 de la primera silva de don Luis: «alga todo y espumas se refiere al peregrino».

Admito que ni las conjeturas sobre las deudas contraídas con el episodio del naufragio de La Odisea, ni tampoco el paralelismo entre el héroe de Góngora y la supuesta parodia del nacimiento de Venus bastan por sí solas para justificar la presencia de los tres sustantivos que don Luis eslabonó al comienzo de la Soledad I: el peregrino, las algas y el escollo. De hecho, solo he registrado dicha terna en la estupenda canción nupcial protagonizada por la Gnósida de Catulo: tanto el «esco\|lo» como las «algas» se dan cita en el Epitalamio de Tetis y Peleo, y lo hacen antes siquiera de que Ariadna rompa a llorar; aunque también después -lo que resulta todavía más significativo-, ya durante el llanto mismo: «ac tum praeruptos tristem conscedere montes» (v. 126); «ille autem prope iam mediis uersatur in undis, / nec quisquam apparet uacua mortalis in alga» (vv. 167-168).

Por último, a zaga de aquella breve tabla (Soledad I, v. 18) a la que el peregrino confió su vida, quisiera detenerme ahora en la sintaxis. Me explicaré: la anástrofe "sustantivo + todo" se repite hasta en tres ocasiones en la Soledad l; y siempre dentro de un paréntesis textual:

1) «Era del año la estación florida / en que el mentido robador de Europa / (media luna las armas de su frente, / y el Sol todo los rayos de su pelo), / luciente honor del cielo, / en campos de zafiro pace estrellas» (Soledad I, vv. 1-6);

2) «(algas todo y espumas)» (Soledad I, v. 26);

3) «al padre de las aguas Ocëano / (de cuya monarquía / el Sol, que cada día / nace en sus ondas y en sus ondas muere, / los términos saber todos no quiere)» (Soledad I, vv. 405-409).

En el primer caso, el del catasterismo referido al signo de Tauro, «el Sol todo» (v. 4) alude a los «rayos» del pelo del «robador de Europa» (v. 2), o sea, al toro, mencionado de forma perifrástica. Según precisó Jammes, hay que escribir aquí «todo», y no «todos», «como imprimen [...] las ediciones modernas. Sol todo se opone a media luna. [Así], el paralelismo de los dos versos se manifiesta también en la acen- 
tuación (3-6-10), mientras [que] "y el sol todos los rayos" daría cierta discordancia con el verso precedente» ${ }^{30}$.

La pregunta de fondo es: ¿nos ayuda este detalle a leer el v. 26 («alga todo y espumas») de la Soledad I? Sí y no. En principio, el heptasílabo de marras «(alga todo y espumas)» debería perfilar el alcance semántico de un sustantivo anterior; pero en esta oportunidad igual de válidos resultarían, por lo que concierne a la sintaxis, tanto el «escollo coronado» (v. 24) como el más lejano -y tal vez más plausible«inconsiderado peregrino» (v. 19). De veras útil, o menos antojadizo, se revela el tercer pasaje que he transcrito, donde el sintagma «términos todos» depende de la «monarquía» del «padre de las aguas Oceano».

Si nos ceñimos al léxico de estos tres paréntesis, cabría arriesgar que las anástrofes del tipo "sustantivo + todo" sirven como aposición, sucesivamente, primero para un toro («mentido robador de Europa» / «sol todo») y después para Neptuno («la monarquía del padre de las aguas Oceano» / «los términos saber todos»). Nótese que ambos sustantivos («robador», o sea, el 'toro'; y «padre de las aguas») poseen corporeidad, y hasta humanidad (o animalidad), considerando que el morlaco es mitificado como un trasunto de Júpiter. Además, los dos -el toro y Neptunogozan de bastante más impronta ovidiana, como poco, que «el escollo coronado / de secos juncos» de los vv. 24-25.

Pero la clave de mi argumento se levanta sobre un paradigma en el que no se ha reparado: Góngora precisa que su «inconsiderado peregrino» (v. 19) fue sorbido y después vomitado cerca de un escollo (v. 24) por Océano (vv. 22-23), justo la deidad que desfilará por los vv. 405-409 de la Soledad I: «el padre de las aguas Oceano». Antes, en definitiva, de recibir la hospitalidad de los pastores «donde halló nido / de Júpiter el ave» (vv. 27-28), esto es, el águila. He aquí, por tanto, el tercer guiño al soberano del Olimpo en apenas 28 versos. A saber: 1 ) «mentido robador de Europa» (v. 2); 2) «cuando el que ministrar podía la copa / a Júpiter mejor que el garzón de Ida» (vv. 7-8), donde «garzón de Ida» equivale al hermoso Ganimedes, el pincerna de los dioses, y, metafóricamente, también al peregrino; y 3) «halló hospitalidad donde halló nido / de Júpiter el ave» (vv. 27-28).

En buena lógica, diríase que Góngora tejió una elusiva red de alusiones: el Sol todo de los rayos de un toro que a su vez era (o había sido) Júpiter tiene mucho que ver con la máscara que el poeta le asignó al sexto duque de Béjar en la Dedicatoria de las Soledades («Pasos de un peregrino son errante»): «iOh tú, que de venablos impedido / -muros de abeto, almenas de diamante-, / bates los montes que de nieve armados / gigantes de cristal los teme el cielo» (vv. 5-8); «las formidables señas / del oso, que aún besaba, atravesado, / la asta de tu luciente jabalina, / - o lo sagrado supla de una encina / lo augusto del dosel, o de la fuente / la alta cenefa, lo majestuoso, / del sitial a tu deidad debido-» (vv. 19-25) ${ }^{31}$. Don Alonso

30. Jammes, en su ed. de Soledades, p. 196. Sobre el catasterismo de la Soledad primera remito a Méndez, 2012, y sobre todo a Blanco, 2016, pp. 311-331.

31. Los términos en cursiva aluden respectivamente a la gigantomaquia («gigantes de cristal»), a una proyección del rayo de Júpiter («luciente jabalina»), al árbol consagrado al señor del Olimpo («encina») y a la identificación del duque de Béjar con dicha deidad. 
Diego López de Zúñiga y Sotomayor era por aquellos años un aristócrata outsider, marginado por la facción del duque de Lerma, que recibió los servicios de un poeta peregrino (Góngora) que había naufragado en un océano (el de la corte de Felipe III) que, convertido en una divinidad ovidiana, y curiosamente de nuevo junto al sustantivo «Sol», reaparece en los vv. 405-409 de la Soledad I: «al padre de las aguas Ocëano / (de cuya monarquía / el Sol, que cada día / nace en sus ondas y en sus ondas muere, / los términos saber todos no quiere)»32.

En resumen, creo haber probado que el extraño paréntesis «(alga todo y espumas)» (v. 26) connota única y exclusivamente al «peregrino» (v. 19), que antes, dentro de la misma Soledad I, había oficiado primero como Ganimedes de un "Júpiter salmantino" que atendía por don Alonso Diego López de Zúñiga; el mismo peregrino, insisto, que luego se nos mostrará como un trasunto de Arión de Lesbos (siglo VII a. C.), juzgado el mejor citarista de su tiempo: «el mísero gemido / segundo de Arión dulce instrumento» (vv. 13-14). Por tanto, de ningún modo el paréntesis «(alga todo y espumas)» puede remitir aquí al inanimado «escollo» (v. 24), un difuso recuerdo de la atroz Escila, que no participa de la isotopía de conceptos (o paradigma) que Góngora fundó entre los sustantivos «Sol», «toro», «Júpiter», «Océano», «peregrino», «Ganimedes», «Arión»y «ave».

\section{LAS QUERELLAS DE ARIADNA (CATULO, EPITALAMIO DE LAS BODAS DE TETIS Y PELEO)}

Dejando a un lado el adorno de las algas - que juzgo menor-, en el resto de los textos homérico-bizantinos aducidos como fuentes para el comienzo de la Soledad 133, y por ello también para presentar al náufrago protagonista, faltaban esas lagri-

32. Según Rojo Vega, 2005, pp. 229-230, «la de Béjar era una de las casas nobles más ricas de España, la más rica quizás, pero no hasta el punto de hacer frente a tantas deudas acumuladas. De modo que la trayectoria de Alonso Diego, como la de su padre, fue vivir al día, ir tirando. Vender posesiones siempre que se lo permitieron, solicitar crecimientos de censos y suspensiones de pagos». Recuérdese también que es moneda común en el Barroco la imagen de la corte como un «mar de sirtes»: en España, «corte se identifica con el lugar de residencia del rey, que viene a ser la ciudad por antonomasia. Es, pues, sede de poder, y por ende escenario de ambiciones y de intrigas, a la par que centro urbano, con todos los atributos que se le acrecen de la antítesis con la sencillez idealizada de la vida campesina» (Morreale, 1958-1959, p. 233). Dicha imagen puede rastrearse en textos de la época, como, por ejemplo, el soneto de Miguel Moreno («Avisar al incauto forastero») que precede a la Guía y avisos de forasteros que vienen a la Corte: «avisar al incauto forastero / en corte, o pleiteante o pretendiente, / del Caribdis o Escila contingente, / peligro oculto y escarmiento fiero» (González Ramírez, 2011, p. 159). Por tanto, no puedo estar de acuerdo con Trambaioli (2015, p. 224) cuando afirma que, «en cuanto a la dimensión autobiográfica, don Luis, [siguiendo las huellas] del Tasso, muestra cómo la identificación del peregrino errante con el poeta se pueda limitar a la esfera panegírica sin la necesidad de verter en la escritura ningún dato personal reconocible». Y tampoco comparto con la estudiosa de Lope, cuyo artículo, por otro lado, vale mucho la pena, que «Góngora calla en los versos del poema el nombre de su prócer, aludiendo al mismo mediante la figura del anónimo príncipe que descuella en la Soledad II al final de la procesión de halconería: "En sangre claro y en persona augusto, / si en miembros no robusto, / príncipe le sucede, abrevïada / en modestia civil real grandeza" (vv. 809-812). Verdad es que la opacidad del fragmento ha confundido a los comentaristas, induciendo a Pellicer y Salcedo a pensar que se trataba del duque de Béjar, mientras Pedro Espinosa ha revelado que se alude al Conde de Niebla, quien heredó el ducado de Medina Sidonia» (Trambaioli, 2015, p. 225).

33. El abad de Rute resumió los principales en su Examen del Antídoto (1617): «De suerte que, o ya se denomine Soledades nuestro poema de la persona principal, que es el pobre náufrago, como denomi- 
mosas querellas que el peregrino «dio al mar» (v. 11) y que, hasta donde alcanzo, solo se habían vertido antes en el carmen 64 de Catulo. Por otro lado, se deberían tomar como los dos primeros rasgos que Góngora le asignó a su héroe el hecho de que «[...] ministrar podía la copa / a Júpiter mejor que el garzón de Ida»; y «náufrago y desdeñado, sobre ausente, / lagrimosas de amor dulces querellas / da al mar [...]» (vv. 7-11) $)^{34}$.

La analogía entre el peregrino de las Soledades y el copero Ganimedes no carece de nervio. Sobre este particular, Jammes se limitó a reciclar la lectura de Salcedo: «dijo que podía servir mejor la copa que Ganimedes para ponderar la hermosura del mancebo, pues fingieron los antiguos poetas que la ocasión del robo de Ganimedes fue su grande belleza» ${ }^{35}$. Empero, Tanganelli y yo mismo sugerimos que, acudiendo a esta perífrasis («garzón de Ida»), don Luis aludía a un poeta peregrino, o sea, a sí mismo, porque el protagonista de sus dos silvas - lo repito- se identifica primero con Ganimedes y luego con el citarista Arión ${ }^{36}$.

Añadiré ahora de mi cosecha que, por boca de Ariadna, Catulo ya había deslizado otro guiño al monte Ida de Creta, el mismo que tuvo que despertar en la formidable memoria de Góngora la orografía de la homónima cumbre de la Tróade a la que fue raptado Ganimedes. No en vano, se trataba de una montaña que Catulo nombra en su carmen 63. Y entiendo que, quizá por ello, las palabras con las que Ariadna se imagina escalando la cumbre del Ida en el Epitalamio de las bodas de Tetis y Peleo, de la que -igual que al náufrago de las Soledades - la separaba un abismo marino («Nam quo me referam? Quali spe perdita nitor? / Idaeosne petam montes? / At gurgite lato / discernens ponti truculentum diuidit aequor», vv. 177-179), no difieren en exceso de las del arranque de la Soledad I:

No bien pues de su luz los horizontes,

que hacían desigual, confusamente

montes de agua y piélagos de montes,

desdorados los siente,

naron Homero su Odisea de Ulises; Virgilio la Eneida de Eneas; de los Argonautas la Argonáutica Orfeo y Valerio Flaco; la Achileide Statio de Achiles; o ya del lugar, como la llíada Homero de Ilio; la Farsalia Lucano de los campos de Farsalia; la Tebaida Estacio de Tebas de Beocia, muy a pelo le viene el nombre de Soledades». Cito por la edición crítica en curso de Matteo Mancinelli (Università di Ferrara), a quien agradezco que me haya facilitado su transcripción del texto de Francisco Fernández de Córdoba.

34. Góngora, Soledades, ed. Jammes, p. 199.

35. Jammes, en su ed. de Soledades, p. 198.

36. Bonilla Cerezo y Tanganelli, 2013, p. 42. Por otra vía, Dolfi (2013, pp. 162-163) ha coincidido con nuestra tesis: «esbozada así, en estos primeros versos, la figura (e historia) del protagonista, y marcada al mismo tiempo su supremacía "metafórica" sobre los demás, Góngora propone a su lector un variado subseguirse de personajes que también quedan enriquecidos y transfigurados por correspondientes alter ego mitológicos. Sin embargo -y no deja de ser significativo- los que se evocan ahora son exempla "menores": sirenas, ninfas, sátiros, etc. Siquiendo matices y situaciones diferentes [...], las serranas se afirman/desmienten como cazadoras-"Ninfas" («sin aljaba», vv. 273-274), como "Bacantes" (sin su "Sileno", vv. 271-272), como "Amazonas" («desarmadas», v. 278), o "verdes Hamadrías" (aunque menos numerosas, vv. 260-262), o más tarde se transforman, por su canto, en "sirenas de los montes" (v. 550). Asimismo a los zagales/as que acompañan a los novios se le identifica con "Sátiros" y "Ninfas" (v. 1079); o a otras "labradoras", numéricamente más reducidas, con un "terno de Gracias bello, repetido / cuatro veces", dentro de las cuales "la más elocuente" destaca como una "dulce Musa" (vv. 888-889, 891)». 
cuando entregado el mísero extranjero

en lo que ya del mar redimió fiero,

entre espinas crepúsculos pisando,

riscos que aun igualara mal volando

veloz, intrépida ala,

menos cansado que confuso, escala ${ }^{37}$ (vv. 42-51).

Luego podemos sacar ya tres conclusiones:

1) el escollo coronado (v. 24) de la Soledad I es una estilización, miniaturizada y en mantillas, de Escila o de Caribdis;

2) a la luz del pasaje del carmen 64 en el que Catulo incluyó a Ariadna trepando por el monte Ida, anterior a ese gesto con el que la hija de rey Minos daría rienda suelta a su llanto en un rocosa playa, el heptasílabo de Góngora, o sea, «(alga todo y espumas)» (v. 26), parece ajustarse mejor al sustantivo escollo - nótese que Catulo se había recreado en la ola junto a la Sirte- que al inconsiderado peregrino del v. 1938;

3) no me atrevo a refutar - de hecho, los confirmaré por otro camino- los corolarios de Pellicer, Alonso, Carreira y Jammes sobre el peregrino; y tampoco esa sensata teoría según la cual ningún ave en su sano juicio pondría secos juncos ni calientes plumas encima de una roca bañada por la marea. Cabría preguntarse, empero, si Góngora no se inspiró, sustituyendo al somorgujo por el alción, e incorporando la idea del nido, en un pasaje del libro V (vv. 124-128) de la Eneida: «Est procul in pelago saxum spumantia contra / litora, quod tumidis submersum tunditur olim / fluctibus, hiberni condunt ubi sedera Cori: / tranquillo silet immotaque attollitur unda / campus et apricis statio gratissima mergis» («Hay a lo lejos, en el piélago, frente a la costa llena de espumas, / una roca que a veces es golpeada y sumergida por el hinchado / oleaje, cuando los invernizos coros ocultan los astros: / con la mar tranquila está en silencio, y se eleva como plataforma sobre las aguas / inmóviles y es posadero gratísimo a los somorgujos amantes del sol») 39 .

Mi tesis es que Góngora hibridó los versos de Catulo sobre Ariadna con aquellos otros de Homero acerca de la llegada de Ulises al país de los feacios. Y también con los de la Eneida. El racionero cordobés daba así carta de naturaleza no solo a una aleación entre los poemas de Homero, Virgilio y el neotérico latino sino también a una imagen soberbia, como es la del náufrago cubierto de algas, que, a su vez, no distaba gran cosa de aquella otra del tritón Palemo en la octava XVI del Polifemo:

37. Góngora, Soledades, ed. Jammes, pp. 207-208. Las cursivas son mías

38. Tan solo por lo que se desprende del carmen 64 de Catulo, pues, como he aducido, entiendo que el paréntesis solo puede aludir al peregrino.

39. Ver Virgilio, Eneida. Volumen II (Libros IV-VI), p. 74. 
Marino joven, las cerúleas sienes

del más tierno coral ciñe Palemo,

rico de cuantos la agua engendra bienes

del Faro odioso al promontorio extremo ${ }^{40}$;

y tampoco hay que olvidarse del «marino dios» que - a guisa de "viejo verde"irrumpe durante la caza de la foca en la Soledad II:

¡Cuántas voces le di! ¡Cuántas (en vano)

tiernas derramé lágrimas, temiendo

no al fiero tiburón, verdugo horrendo

del náufrago ambicioso mercadante,

ni al otro cuyo nombre

espada es tantas veces esgrimida

contra mis redes ya, contra mi vida,

sino algún siempre verde, siempre cano

Sátiro de las aguas, petulante

violador del virginal decoro,

marino dios que, el vulto feroz hombre, corvo es delfín la cola! (vv. 453-464) ${ }^{41}$.

Por último, y pido perdón por el abuso de la autocita, Paolo Tanganelli y un servidor opinamos que no se ha hecho hincapié en otra pincelada de los vv. 21-28 de la Soledad I:

... la imagen de la roca rodeada por olas se repite a menudo en la emblemática (se halla, por ejemplo, en los repertorios de Ruscelli y Capaccio). Los versos de Covarrubias que acompañan a esta res picta avalan que dicho símbolo podría

40. Góngora, Fábula de Polifemo y Galatea, p. 160; ver también Bonilla Cerezo y Tanganelli, 2016, pp. 242-244. Góngora había adelantado ya esta imagen en la canción De los marqueses de Ayamonte, cuando se entendió que pasaran a nueva España: «Verde el cabello undoso, / y de la barba al pie escamas vestido, / aliento sonoroso / daba Tritón a un caracol torcido, / y en las alas del viento / voló el son por el húmido elemento» (1606, vv. 1-6) (<http://obvil.sorbonne-universite.site/corpus/gongora/ gongora_obra-poetica\#poem165>). Ver asimismo la nota que Vázquez Siruela (2017) le copió a Díaz de Rivas: «Cuentan las fábulas que Ino, mujer del rey Ataniente, llena de furor se subió a una alta roca y, desde allí, con su hijo Melicerta en los brazos, se arrojó al mar donde, por ruegos de la diosa Venus, fueron convertidos en dioses marinos, y ella fue llamada Leucothea y él, Palemo. Ver la fábula en Ovidio, lib. 4, Metamorfosis. Y aunque algunos pudieran decir que Palemo era niño, incapaz de enamorarse, con todo ello, autores le pintan como un varón perfecto. Claudio, in Epitalamio Honorii, lo describe caballero enfrenando un delfín y Apuleyo, lib. 4, Metam. lo finge cochero de Neptuno. Lo mismo dice Filóstrato, lib. 2, Iconum, y Arístides in Istmica». La cursiva es mía. Y continúa Vázquez Siruela: «El faro de Sicilia es famoso, es una torre orilla del mar junto a la ciudad de Mesina. Tiene en la parte superior gran lumbre, con que señala a los navegantes se guarden del mar vecino, lleno de escollos e innavegable por aquellos golfos [f. 33v] de Caribdis. Y el peñasco de Sicilia tomó su nombre de la otra célebre torre de faro en Egipto a cuya imitación se hizo, Volaterrano, lib. 6. Por el promontorio extremo se entiende el más distante de esta torre, de los tres que tiene Sicilia». El propio anticuario sevillano adujo una fuente de Bernardo Tasso - creo que no se ha citado nunca- en la que, precisamente, asoma el sustantivo «alga»: «Dioses marinos con guirnaldas de coral introduce B. Tasso, cant. 39 del amad., p. 239: "Veniuno y dei del mar tutti al'intorno / gli hispidi crin d'alga in coronati / e qual di perle e di coralli adorno / qual di fior colti ne vieini parti"». La cursiva es mía.

41. Góngora, Soledades, ed. Jammes, pp. 483-485. 
resaltar las angustias amatorias de un náufrago «desdeñado» y «ausente» [que en el fondo son los mismos pesares de la Ariadna de Catulo]: «Cual el peñasco que del mar ceñido / y de espumosas ondas azotado, / de furiosos vientos combatido, / con perpetua tormenta está cercado: / tal debéis figurar un afligido / corazón de pasiones rodeado, / herido de uno y otro pensamiento, / verdugos de su pena y su tormento». Pero el escollo irrumpe asimismo como una sinécdoque del locus amoenus que el anónimo forastero descubrirá al día siguiente. No se olvide además que en el v. 187 asoma otro islote -(«verde balcón del agradable risco», I, v. 193) - que le permite [al peregrino] contemplar y describir esa soledad («lugar despoblado») ante la cual «muda la admiración habla callando» (I, v. 197). Pues bien, si en el emblema de Alciato Ex pace ubertas un alción se apresuraba a fabricar su nido sobre un escollo (señal de que el mar estaba en calma), [el escollo de Góngora] se alza coronado por «calientes plumas» aguileñas: luego el náufrago «halló hospitalidad donde halló nido / de Júpiter el ave» (I, vv. 27-28). Y el ave de Júpiter remite tanto al emblema de Ganimedes cuanto a otro de Alciato, Signa fortium (Las armas de los fuertes) [...], en el que se define a esta rapaz -en palabras de Daza Pinciano - como «Al hijo de Saturno ave sagrada». No podía ser otra: el águila [tenía que] presidir el primer escollo coronado por el náufrago para anunciarle que el retiro ducal -o sea, las heredades de ese Júpiter [castellano] que fue don Alonso Pérez de Guzmán, luego metamorfoseado (por no decir que disfrazado), dentro de la primera de las silvas, en «cabrero» $(1,213)$ y en «político serrano de canas grave» $(1,364-365)$-, es su tierra de acogida ${ }^{42}$.

Con este par de trazos emblemáticos, Góngora se libró de contarnos -en esencia porque los había esbozado ya con palabras que remiten a las glosas de las empresas de Girolamo Ruscelli, Giulio Cesare Capaccio y Andrea Alciato- las cuitas amorosas de su peregrino, evocadas mediante las divisas del «escollo» y del «alción». Y lo hizo de acuerdo con una técnica que oscila entre lo omitido a sabiendas y lo oblicuamente revelado. Una poética original, en suma, a caballo entre la aposiopesis y la sinécdoque, que remontaba al carmen 64 de Catulo, «poema metonímico [en el que] aparece todo lo que rodea a la boda, menos la boda, por lo que resulta [cuando] menos irónico titular o hablar o considerar el poema como el de las bodas de Tetis y Peleo por encima de otros temas. Y lo que se dice de esta boda también se puede afirmar de la de Teseo y Ariadna, deseada por ella, pero que jamás se produjo» ${ }^{43}$.

\section{UN MARÍTIMO ALCIÓN (OVIDIO, METAMORFOSIS, XI, VV. 410-748)}

Después de publicar mi trabajo a cuatro manos junto a Tanganelli (2016), me salieron al paso un par de hipotextos que clarifican el íncipit de la Soledad de los campos, según la bautizara Díaz de Rivas. El primero no es mío, ya que me lo ha sugerido la lectura de un cumplido artículo de Gerhard Poppenberg sobre la Fábula de Polifemo y Galatea: cuando el estudioso alemán comenta la imagen del cíclope sentado sobre la roca, subraya que dicha identidad no tarda apenas en deslizarse hacia el alción («Marítimo alción roca eminente / sobre sus huevos coronaba el

42. Bonilla Cerezo y Tanganelli, 2013, pp. 44-46. Los corchetes son míos.

43. Fernández Corte, 2006, p. 646. 
día / que espejo de zafiro fue luciente / la playa azul de la persona mía», 1612, vv. 417-420 ${ }^{44}$, ave que protegía su nido encima de otro risco; igual que antes la ninfa Galatea, esta vez en figura de águila (1612, vv. 261-262): «no el ave reina así el fragoso nido / corona inmóvil, mientras no desciende» ${ }^{45}$.

He aquí una octava, la LIII, cuyas imágenes coinciden con las de la obertura de la Soledad I, que trajo de cabeza a todos los gongoristas del Barroco. Verbigracia, Alfonso Reyes copiaría una epístola que Juan de Nadal envió a Zaragoza a Andrés de Ustarroz, con fecha del 31 de agosto de 1634. En ella se lee lo siguiente:

En cuanto a «Marítimo alción, roca eminente sobre sus huevos coronados», digo que, si yo dije que roca eminente era apósito de Alción, lo dije fundado en que dice Ovidio que esta ave hace su nido sobre el mar, y no sobre escollo, como quiere don Luis; y, teniéndome a Ovidio, hacía apósito a lo que don Luis acusativo; que ha de ser así para que la oración sea congrua. Pero si se ha de entender que esta ave hace su nido en el mar mismo, ha de ser apósito roca eminente, y no acusativo; porque si el lugar de los huevos es el mar, y no la roca, luego [el ave] no corona la roca, sino el mar, pues él está en el nido. Mas don Luis quiere que el nido esté en la roca y no [en] el mar, y ansí es el texto 46 .

Ya construyera el alción su nido sobre el mar, o bien coronando la roca, tanto nos da, por más que esa decisión incida sobre los vv. 22-28 de la Soledad primera, según veremos, lo sugestivo es que Poppenberg recuerda que

Ovidio narra la transformación de Alcíone en las Metamorfosis (XI, 410-748): [...] Alcíone es la esposa de Céix, que viaja por el mar. Su barco se hunde durante una violenta tormenta en la cual el cielo y el infierno se ponen en correspondencia: el océano parece tocar el cielo y se abre hasta las profundidades del Aqueronte (XI, 497-506). El naufragio se nos presenta con detalle a lo largo de noventa versos. En su punto culminante Ovidio evoca el amor de Céix, que muere pensando en su mujer, de tal forma que en este epilio el amor y la muerte son diseñados bajo el signo del naufragio. Alcíone se entera de la muerte de su marido cuando Juno envía a Iris - la mensajera de los dioses - desde el Olimpo a la frontera del infierno en el oeste, formando así otra correspondencia de cielo e infierno. Ahí se levanta una montaña con una caverna, en la cual vive Somnus -igual que Polifemo en la suya-, sumido en una oscuridad brumosa y entre dos luces (XI, 592 y ss.). [...] De la roca de esa montaña nace -igual que de esa otra montaña que es Polifemo (1612, 5, 57-58) - la corriente del Leteo. En esa cueva en la frontera del infierno y del reino de los muertos vive Somnus rodeado por imágenes oníricas. Iris le encarga que informe a Alcíone del naufragio de Céix; y para ello Morfeo, el configurador de imágenes, se le aparecerá en un sueño bajo la hechura del marido. Alcíone se dirige desolada al mar, donde ha sido arrastrado el cuerpo del navegante. Y juntos son transformados en aves, en un par de alciones que continúan disfrutando de su amor tras la metamorfosis ${ }^{47}$. 
Me pregunto si junto al conocido magisterio de Homero, Virgilio, Dión Crisóstomo y Tasso, además de Catulo, no habría que añadir aquí el de Ovidio; y no solo como autoridad capital -y evidente, al lado de los italianos Stigliani48 o Marino ${ }^{49}$ para el diseño del Polifemo, sino del arranque de las Soledades, una obra juzgada hasta la fecha bastante más virgiliano-sannazarista que ovidiana ${ }^{50}$.

Que yo sepa, ninguno de los zoilos del Seiscientos, ni tampoco de los del siglo pasado y lo que llevamos del actual, han acudido a las Metamorfosis para hablar del pórtico de la Soledad de los campos. ¿Y si uno de los modelos sobre los que Góngora edificó su primera silva hubiera estado siempre ahí, a la vuelta de la esquina, sin que reparásemos en él, absortos como andábamos a la caza y captura de fuentes cada vez más remotas? ${ }^{51}$

Al inicio de las Soledades el águila se nombra dos veces como símbolo jupiterino: «cuando el que ministrar podía la copa / a Júpiter mejor que el garzón de Ida» (vv. 7-8); y «halló hospitalidad donde halló nido / de Júpiter el ave» (vv. 26-27). Y entre ambas Góngora deslizó otro guiño ornitológico -implícito y un punto furtivo-al alción: «no lejos de un escollo coronado / de secos juncos, de calientes plumas» (vv. 23-24). En apariencia, al leer los vv. 23-27 se antojaría casi inevitable deducir una relación de causa y efecto entre el águila, el único de los pájaros cuyo nido se cita, y esas «calientes plumas» que coronaban el escollo.

Pero no caigamos en un error tan craso, ya que por este umbral del poema parece aflorar, más bien, un eco de la Fábula de Polifemo, donde Góngora había metaforizado ya a Galatea como águila, y al cíclope como alción. Con otras palabras -y de acuerdo con la exégesis de Juan de Nadal, que no iba nada desnortado-, entiendo que don Luis alude aquí a dos nidos muy distintos: el del alción y el del águila. Es por eso que escribió al comienzo de la Soledad I que su peregrino había desaguado en la playa, «no lejos de un escollo coronado / de secos juncos y calientes plumas» que, a mi juicio, solo pueden ser las del alción, una coraciforme que habita en lagos y ríos de Europa, África y Asia; mientras que, no mucho después, el mismo náufrago

48. Alonso, 1982, pp. 525-539; Poggi, 2009, pp. 187-206.

49. Bonilla Cerezo y Garosi, 2008.

50. Remito a Cacho Casal, 2007; y a Blanco, 2014

51. Acierta Blanco (2016, p. 344) al señalar que «parece ocioso empeñarse en probar que Góngora admiraba a Ovidio y que en las obras del poeta latino halló materiales e ideas para elaborar sus poesías. Baste recordar dos hechos notorios que no dejan duda sobre esta afinidad y filiación ovidianas. Dos de sus cuatro poemas extensos y ambiciosos, el Polifemo y la Fábula de Píramo y Tisbe, elaboran historias directamente sacadas de las Metamorfosis. En la "carta en respuesta" en que defiende las Soledades frente a los sarcasmos de sus adversarios, Góngora cita las Transformaciones de Ovidio como un ejemplo de oscuridad que justificaría la suya: "[si la obscuridad y el estilo intrincado de Ovidio (que en lo de Ponto y en lo de Tristibus fue tan claro como se sabe, y tan obscuro en las Transformaciones) da causa a que, vacilando el entendimiento en fuerza de discurso, trabajándole (pues crece con cualquier acto de calor), alcance lo que así en la letra superficial de sus versos no pudo entender luego, hace de confesar que tiene utilidad avivar el ingenio, y eso nació en la obscuridad del poeta. Eso mismo hallará vuestra merced en mis Soledades, si tiene capacidad para quitar la corteza y descubrir lo misterioso que encubren]". Cabe desde luego preguntarse lo que quiso decir con ello, pero es un hecho que el poeta de Sulmona es el primer modelo legitimador que se le ocurre cuando emprende su propia apología». Procuro ampliar aquí la relación de Góngora con Ovidio, tanto por lo que respecta al argumento del Polifemo y la Tisbe, según advirtiera Blanco, como al de las mismísimas Soledades. 
«halló hospitalidad donde halló nido / de Júpiter el ave», o sea, la morada de la reina de las rapaces, situada entre los «riscos que aun igualara mal volando / veloz intrépida ala» (vv. 49-50). A saber: la cumbre hacia la que escala el desdeñado forastero, rumbo a la cabaña de los pastores (vv. 58-62).

Harto increíble que un águila cazara en mar abierto, y no digamos ya que pusiese sus huevos a ras de suelo o encima de las olas. Se trata de dos aves y de dos nidos. Y no es cosa baladí. Si en virtud del resumen del idilio entre Alción y Céix que le tomo prestado aquí a Poppenberg podría creerse que la Ariadna del Epitalamio de Tetis y Peleo acaso le sirvió a Góngora como piedra de toque para dar forma a su peregrino, todavía más claros se me antojan los rescoldos de este mito de Ovidio, que, abocetado hasta casi rozar la elipsis («no lejos de un escollo»), don Luis esperaba que su avisado lector atisbara bajo la hechura -y el llanto- del náufrago «sobre ausente».

Basta asomarse a los versos del libro XI de las Metamorfosis, tal vez en la traducción en tercetos y octavas reales de Pedro Sánchez de Viana (1589), que no debía faltar en la biblioteca del poeta52, para toparse con más de uno y hasta de dos episodios sospechosamente parecidos.

Detengámonos primero en la escena, tan semejante a la de la Ariadna de Catulo, en la que Alcíone ve cómo zarpa su marido:
Con tal promesa en parte consolada,
la nave a su viaje conveniente,
con jarcias, chusmas y armas fue fletada.
la cual vista de Alcione, en sí siente
horror, y fue señal de mal agüero,
de mal agüero claro y evidente.
$Y$ vertiendo mil lágrimas primero,
a su marido y vida está abrazada,
y con semblante triste, lastimero,
y diciendo «adiós», cayose desmayada ${ }^{53}$.

La protagonista de esta historia es una mujer, como en el Epitalamio de Catulo; lo que nada obsta para que un artista de las prendas y los vuelos de Góngora le otorgase varios de sus rasgos al peregrino: «náufrago y desdeñado, sobre ausente, / lagrimosas de amor dulces querellas / da al mar, que, condolido, / fue a las ondas, fue al viento, / el mísero gemido / segundo de Arión dulce instrumento» (vv. 9-14). Considérese además que el propio Catulo, allá por el siglo I a. C., había acuñado la licencia de

ocupar todas las posiciones de la primera persona en los poemas narrativos y en sus partes dramáticas. Lo contemplamos diseñando distintas funciones [...] para el narrador, o dando la palabra a los personajes y fundiéndose con ellos, de tal manera que adopta distintas posiciones de sujeto, no solo en los planos narratológico 
o psicológico -a la manera [en] que Homero se mudaba en Agamenón cuando este hablaba-, sino también ideológico o de género (hablar como un eunuco, hablar como una mujer) ${ }^{54}$.

He aquí la cuestión palpitante: Góngora hizo hablar e incluso llorar a su peregrino según el modus operandi de la Ariadna de Catulo en el carmen 64 y de la Alcíone del libro XI de las Metamorfosis de Ovidio. También por este motivo Wilamowitz se arrogó hace varias décadas el primado de intuir en el pecho de la hija del rey Minos «los latidos del corazón del poeta» ${ }^{5}$. Luego no sorprenderá que hoy se admita ya sin titubeos «la identificación del Catulo abandonado [por Clodia (Lesbia)] con [...] Ariadna, continuando así una feminización (o, peor visto, una apropiación de la voz de la mujer) ya mostrada en los poemas cortos [del veronés]»56.

Pero este encuadre de las Soledades bajo la lente del mito ovidiano permite ir un poco más lejos, toda vez que Góngora concibió a su náufrago como una fusión entre Alcíone y Céix, quien, a diferencia del errante héroe de las silvas del cordobés, que sí logrará salvar la vida, no había sido desdeñado. Ya durante la travesía del propio Céix -y conviene leer estos tercetos al trasluz de una hipálage gongorina: «montes de agua y piélagos de montes» (v. 44) ${ }^{57}$ - se nos dice que

La celestial región parece llena de olas, y las nubes rociadas; y otras veces se ve la roja arena y con ella las aguas coloradas, y a ratos está el mar ennegrecido, sus espumosas olas allanadas ${ }^{58}$.

54. Fernández Corte, 2006, p. 95.

55. Cit. por Fernández Corte, 2006, p. 96

56. Fernández Corte, 2006, p. 96.

57. Ver Martín Morán, 1999, pp. 866-867. En mi opinión, la mitad de dicha hipálage procede de la tempestad en las islas Egimoros, dos islotes o bajíos junto a la bahía de Cartago, del libro I (vv. 102-112) de la Eneida: «Talia iactanti stridens Aquilone procela / uelum aduersa ferit fluctusque ad sidera tollit. - Fraguntur remi, tum prora auertit et undis / dat latus: insequitur cumulo praeruptus aquae mons. / Hi summo in fluctu pendent, his unda dehiscens / terram inter fluctus aperit: furit aestus harenis. / Tris Notus abreptas in saxa latentia torquet / (saxa uocant Itali mediis quae in fluctibus Aras, / dorsum immane mari summo), tris Eurus ab alto / in breuia et Syrtis urget (miserabile uisu!) / illiditque uadis atque aggere cingit harenae» («Mientras esto profiere, una tormenta, silbando por el aquilón, / de bolina desgarra la vela y alza a los astros el oleaje. / Se quiebran los remos, luego cambia el sentido de la proa y a las olas / ofrece el costado: con su descarga le sigue escarpada montaña de agua. / Unos cuelgan de la cresta del oleaje, a otros el agua, hendiéndose, / les abre el mar la tierra entre el oleaje: la corriente enloquece de arenas. / A tres el Noto las desvía arrastrándolas contra rocas ocultas / (rocas que, en medio del oleaje, los ítalos llaman Altares, / lomo desmesurado en la faz de la mar), a tres el euro desde las profundidades / contra bajíos y Sirtes apremia (ipenosa visión!) / y estrella en los vados y envuelve con talud de arena»). Ver Virgilio, Eneida. Volumen I (Libros I-III), pp. 12-13.

58. Ovidio, Las metamorfosis, p. 450, vv. 927-932. 
Atendamos ahora al llanto de Céix en pleno naufragio:

Del padre y madre aquel se está acordando;

la casa mueve a este y la hacienda;

cualquiera está en aquello imaginando

a donde el corazón dejó por prenda.

A Céix solo Alcíone movía

con afición tiernísima, estupenda.

Su nombre cien mil veces repetía,

y aunque con gran deseo la desea

se goza que en la nave no venía ${ }^{59}$.

Aún más transparente resulta el paralelismo entre los versos de Góngora en la Soledad I («Del siempre en la montaña opuesto pino / al enemigo Noto / piadoso miembro roto, / breve tabla, delfín no fue pequeño / al inconsiderado peregrino / que a una Libia de ondas su camino / fio, y su vida a un leño» ${ }^{60}$ ) y los del texto que pudo servirle como falsilla:

Mas otros, agarrados a tablones,

procuran escapar de aquella vía,

del agua, y sus angustias y aflicciones.

Y Céix, con la mano que solía

tener el real cetro, tiene agora

la parte de la nave que podía.

Favor de suegro y padre en vano implora

$y$, mientras nada, siempre va nombrando

a Alcíone, su mujer y su señora ${ }^{61}$.

Y qué decir de la refinadísima escena en la que, gracias a la mediación de Morfeo, Céix se le aparece en sueños a su esposa:

Muerto soy ya; no creas al deseo

ni a la esperanza vana, porque sabe

que destrozó en el hondo mar Egeo

el nubiloso Ábrego mi nave.

Las olas una a una, y mil arreos,

entraron por mi boca, que el suave

y amado nombre tuyo allí nombraba

que tu favor en vano yo imploraba ${ }^{62}$.

Por último, voy a transcribir el planto de Alcíone en la orilla, una vez ha concluido el interludio onírico en el que Céix - como el héroe de las Soledades: «Desnudo el joven, cuanto ya el vestido / Ocëano ha bebido» (Góngora, vv. 34-35) - desfilaba en paños menores («Desnudo estuvo aquí, descolorido, / el cabello mojado [...]»,

59. Ovidio, Las metamorfosis, p. 452, vv. 1005-1013.

60. Góngora, Soledades, ed. Jammes, p. 201; I, vv. 15-21.

61. Ovidio, Las metamorfosis, p. 453, vv. 1035-1043.

62. Ovidio, Las metamorfosis, p. 458, vv. 1235-1242. 
Ovidio, vv. 1288-1289)63. El vate andaluz probablemente decidió omitirlo en la Soledad I («lagrimosas de amor dulces querellas», v. 10) para sustituirlo por el devoto apóstrofe que el náufrago ("Oh bienaventurado / albergue a cualquier hora...», vv. 94-135) endereza a la cabaña de los pastores; y más aún por el métrico llanto en estancias aliradas que entonará en la Soledad II (vv. 116-189)64.

Pero Ovidio ya le había regalado a Alcíone estas palabras:

Y habiéndose la triste allí parado,

mientras decía: «En este mismo suelo

a mi marido y bien tuve abrazado.

Aquí se despidió, y al leve vuelo

soltó la nave»; y mientras que notaba

lo que pasó con sumo desconsuelo,

miró el furioso mar, vio que bajaba

por él un no sé qué, que parecía

ser cuerpo, y al principio se dudaba

lo que era; mas al fin, ya que venía

más cerca, aunque estaba bien distante,

que fuese cuerpo muerto conocía,

y náufrago; mas viéndose ignorante,

¿quién era?, del agüero conmovida,

de lágrimas piadosas fue abundante,

y dijo: «Desdichada fue nacida

tu mujer, si la tienes, joh cuitado!,

que acabaste en el mar la triste vida».

Más cerca con las olas allegado

el cuerpo, cuanto más le está mirando,

más fuera de juicio se ha quedado.

$Y$ a la ribera misma ya llegando

que puede conocerse, vido que era

su Céix, y al momento lamentando,

63. Ovidio, Las metamorfosis, pp. 459-460.

64. Ver Roses, 1997. Recientemente, Trambaioli (2015, pp. 224-225) ha planteado de manera convincente que en el libro I de El peregrino en su patria de Lope (1604), «Pánfilo de Luján llega náufrago a la playa de Barcelona y, cerca de una cabaña, oye el canto de un pescador desesperado; de repente unos bandoleros interrumpen su plática y el peregrino acaba por aceptar la hospitalidad en las humildes casas de estos. [...] Yendo más en detalle, tengo que confesar que por mucha interdiscursividad que se pueda producir en el ámbito de la lírica haliéutica, a mí me parece imposible que el "métrico llanto" [en la Soledad II] del protagonista gongorino no sea la respuesta de don Luis a los fragmentos lopescos [comentados por Trambaioli en su artículo] de la Arcadia, de La hermosura de Angélica y, sobre todo, del Peregrino. Señalo un par de ecos [...] sospechosos. En el I libro de la novela de aventuras, Pánfilo, herido y encarcelado, canta desconsolado un soneto; evocando el naufragio que lo ha llevado a la playa barcelonesa, separándolo de su amada, así recuerda el momento en que la "mísera nave" se deshace por la embestida del mar furioso: "Abriose, y quiso una piadosa tabla / ser mi delfín y rota y combatida / al fin es hoy la que mi historia cuenta". En la Soledad I, [según hemos visto], la voz poética describe cómo el protagonista se ha salvado del naufragio echando mano por lo menos de cuatro elementos léxicos empleados por Lope: "piadoso miembro roto, / breve tabla, delfín no fue pequeño, / al inconsiderado peregrino"». ¡Chapeau!, pero faltan las «lagrimosas de amor dulces querellas» (Soledad I, v. 10), el «escollo coronado / de secos juncos, de calientes plumas» (Soledad I, vv. 24-25) y el heptasílabo «(alga todo y espumas)» (Soledad I, v. 26). De ahí, entiendo, la utilidad de mi trabajo. 
diciendo: «Este es», con rabia fiera

la cara, y el cabello, y el vestido

destroza, cual furiosa lastimera.

Y las temblantes manos ha extendido

a Céix muerto, y dice de esta suerte:

«¿A mí volvéis, carísimo marido?».

De cal y canto hecho estaba un fuerte

cercano al agua, cuya furia y ola

se quiebra en él, y en mansa se convierte.

Aquí se sube, y harto fue que sola

pudiese; mas no fue, porque volaba,

y con las nuevas alas con que vola,

las enemigas aguas apretaba;

y en ave miserable convertida,

un llanto con el pico comenzaba

a do su queja está bien conocida.

Mas ya que el mundo cuerpo muerto toca,

con las recientes alas a él asida,

hizo el oficio el pico de la boca,

porque besó mil veces al marido,

de donde no ha nacido duda poca,

que el pueblo no sabía si conmovido

el cuerpo, de las olas se movía,

o porque realmente lo ha sentido.

Mas verdaderamente lo sentía,

que la misericordia soberana

a cada uno en ave convertía.

$Y$ aun entonces se amaron tan de gana,

que la matrimonial fe que tenían,

en aves transformados, quedó sana.

A su tiempo se juntan, juntos crían

en el invierno, y días sosegados

sobre el mar, de quien algo ya se fían,

pendientes nidos forjan, y contados

siete continuos días está echada

Alcíone en sus huevos muy amados ${ }^{65}$.

Si se da por bueno mi silogismo, "Céix + Alcíone = peregrino", valdría especular también con la opción de que, en el caso de que el proyecto inicial de cuatro Soledades no hubiese quedado trunco, el náufrago protagonista se hubiera reunido - vivo o muerto - con su ingrata dueña, fuera esta o no algo desabrida.

Y no acaba aquí la cosa, porque he apuntado ya la importancia del segundo nido: el del águila, emblema de Júpiter, o sea, el mismo dios que Góngora había identificado en su silva-Dedicatoria a las Soledades («Pasos de un peregrino son errante») con el duque de Béjar («del oso que aun besaba, atravesado, / la asta de tu luciente jabalina, / o lo sagrado supla de la encina / lo augusto del dosel, o de la 
fuente / la alta zanefa lo majestüoso / del sitïal a tu deidad debido», vv. 20-25) ${ }^{66}$, y a la vez con «una constelación, tanto boreal como austral: en ella resplandece Altair, guía de todos los aventurados navegantes que se lanzaron a surcar los océanos» ${ }^{67}$. Pues bien, esa transición entre los dos nidos de las aves, y por ello la bisagra para este palimpsesto ovidiano (Alción y Céix) de la Soledad ${ }^{68}$, alcanza pleno sentido al considerar que, en otra versión del mismo relato (Seudo-Apolodoro, Biblioteca mitológica, I, 7, 4), Alcíone y Céix se atrevieron a igualarse con Hera y Júpiter, lo que daría pie a que la hija de Eolo fuera transformada en alción y el rey de Traquis en somorgujo, ave que se define por su dotes para la natación e incluso para el buceo; dos de las cualidades que, en principio, adornaban al errante peregrino de Góngora, aunque solo sea porque le valieron para salvar el pellejo ${ }^{69}$.

\section{OLIMPIA Y BIRENO (ARIOSTO, ORLANDO FURIOSO, X-XI)}

He subrayado antes que pudo existir otro modelo para el pórtico de las Soledades: una tesela, ahora renacentista, si bien anclada a los mitos de Catulo y Ovidio. Me refiero al Orlando Furioso de Ariosto, uno de los libros de cabecera de Góngora.

66. Góngora, Soledades, ed. Jammes, p. 187. Sobre este particular ver Bonilla Cerezo y Tanganelli, 2013, pp. 36 y 41: «Es como si don Luis hubiese querido colocar en el centro del escudo de los Zúñiga (del que recicla solo la orla: ["déjate un rato hallar del pie acertado / que sus errantes paso ha votado / a la real cadena de tu escudo", Dedicatoria al duque de Béjar, vv. 30-32]) una empresa (o más bien toda una guirnalda de ellas) que, según veremos, hacen hincapié en la índole jupiterina del sujeto alabado: porque Júpiter, como nadie ignora, es el dios de la hospitalidad (Zeus Xenios). [...] Nótese que la "luciente jabalina" que porta consigo don Alonso para atravesar al oso (vv. 20-21) tiene más de un parecido, por su tamaño y fulgor, con otro de los atributos de Júpiter: el rayo en la mano derecha, con el que avanza como báculo de poder o arma arrojadiza. Una imagen de este jaez, asociada con el padre de los dioses, e inspirada acaso [...] en un fragmento de los Fesceninos que Claudiano compuso con ocasión de las bodas del emperador Honorio, resucita en el Panegírico, cuando don Luis nos muestra a Lerma en calidad de industrioso rejoneador: "Tal vez la fiera que mintió al amante / de Europa, con rejón luciente agita" (1617, vv. 65-66)».

67. Cancelliere, 2010, p. 76.

68. Me separo un punto de esta ocurrencia, diríase que boutade, de Rico (1987, p. 109: «uno tiene la impresión de que [Góngora] siempre mantuvo frente a la lengua sabia la actitud -tan estudiantil- de quien no llegó a sentirla como natural, captándola y disfrutándola sin necesidad de reducirla, palabra por palabra, a cada uno de sus supuestos equivalentes en vernáculo». Según Mazzocchi (2008, p. 72), «por lo que se refiere a los clásicos, [...] [sus] lecturas debían realizarse bien en el texto original, bien (donde las había y a menudo había varias) a través de las traducciones. [...] Pero importa subrayar que el doble acceso quedará sin duda justificado; y no se trata tanto de pensar en un Góngora poco ducho en latín y que necesita apoyarse en la versión romance de las páginas inmortales de los clásicos. El racionero, está claro, no tenía el enfoque y las fuerzas de un clasicista, y, aun sabiendo sus latines, no llegaba tal vez al libre gozo estético del verso latino como si de castellano se tratara. Pero esto no excluye el acceso directo al texto original. De las versiones, sin embargo, lo que sí debía interesarle (y pienso sobre todo en el caso de Ovidio) era la técnica de recreación artística de un modelo, ya que nos movemos todavía por una poética donde la imitación se considera como base para cualquier acto creativo y donde la traducción es todo menos una práctica pasiva». Por su parte, Pérez Lasheras (2008, p. 132), observa que «Góngora no leía los textos clásicos como filólogo, sino como un poeta; no estaba tan atento a una determinada construcción o a la procedencia de una figura curiosa, sino que se guiaba principalmente por su intuición y por la belleza de las expresiones. De ahí que se quedara con un determinado eco, con una evocación, con un recuerdo concreto».

69. Remito de nuevo a la nota 15. 
Hasta donde conozco, más allá del capital ensayo de Chevalier (1968), los préstamos del poeta ferrarés - a quien por cierto Montaigne relacionó con Ovidio ${ }^{70}$ - en el corpus de don Luis solo han merecido cuatro asedios. En el primero, Andrea Bresadola subrayó que, desde la época de Pellicer, Salcedo y el abad de Rute, se viene insistiendo en el parentesco entre ambos ${ }^{71}$. Empero, ni en sus notas sobre los sonetos «Qual avorio di Gange o qual di Paro» y «Cuál de Ganges marfil, o cuál de Paro», ni en las formidables de Lara Garrido acerca del romance de Angélica y Medoro («En un pastoral albergue», 1602) ${ }^{72}$, ni tampoco en las de Dámaso Alonso ${ }^{73}$, y finalmente en las de José María Micó a propósito de las huellas del romanzo en la Fábula del cíclope, al margen de la feliz «ariostización» de las traducciones renacentistas de Ovidio que eligieron el molde de la octava -las de Lodovico Dolce (Gabriel Giolito, 1553) y Giovanni A. Anguillara (1561)-74, se ha puesto el acento sobre un episodio que pudo prender la mecha que encendería la fragua de las Soledades y que de nuevo remite a las Metamorfosis: en los cantos X y XI del Furioso se nos relata la peripecia de Olimpia, hija del rey de Frisia, a quien sus padres decidieron casar con el hermano de Bireno, aunque en realidad era este último quien la pretendía. A lo largo del relato, con estimables parecidos con el íncipit de las silvas de Góngora, Ariosto describe cómo mientras Bireno navegaba hacia Zelanda, un torbellino lo sorprendió en alta mar, obligándolo a hacer escala en un islote (picciol seno) donde, por fin, se las ingeniará para yacer con Olimpia. Al amanecer, mientras la princesa aún duerme, el lascivo amante pondrá pies en polvorosa y levará anclas, dejándola sola en aquella playa.

No extrañará, pues, que, al tramontar del sol, la dama despierte y termine deshaciéndose en lágrimas, si bien de una forma más que mítica y ovidiana:

Rimase a dietro il lido e la meschina

Olimpia, che dormì senza destarse,

fin che l'Aurora la gelata brina

da le dorate ruote in terra sparse,

e s'udîr le Alcione alla marina

de l'antico infortunio lamentarse.

70. Blanco (2016, p. 345) opina que «Ovidio y Ariosto, en su personalidad y trayectoria, son espejos en que puede mirarse el poeta cordobés en este momento decisivo que se inicia con su vuelta a Córdoba en octubre o noviembre de 1609. En la tranquilidad de una nueva y agradable casa, consigue pronto liberarse en parte de las rutinas de su oficio de racionero, y emprende la redacción de poemas de más vuelos y extensión que todo lo escrito hasta entonces, iniciando una fase de creatividad sin parangón que concluye desdichadamente con su decisión de mudarse a la corte en 1617 por imperativos económicos. Góngora, que, en los treinta años que separan sus primeros escarceos poéticos de esta fase de fiebre creativa que culminó en las Soledades, se había dado a conocer como maestro de aqudezas y donaires, como le conceden sus mismos detractores, contempló sin duda su propia figura en un Ovidio que pasa de ser un poeta elegíaco y amatorio a ser cantor seriamente romano del nuevo calendario instituido por Augusto y de la majestad de los dioses, o en un Ariosto, autor de comedias y sátiras, y finalmente de un largo romanzo, el Orlando furioso, a ojos de muchos máximo ejemplo de "poema heroico"». Sobre este período, ver el libro coordinado por López Bueno, 2011.

71. Bresadola, 2008, pp. 161-172.

72. Lara Garrido, 2009.

73. Alonso, 1982, pp. 348-352.

74. Micó, 2015, pp. 305-319. 
Né desta né dormendo, ella la mano per Bireno abbracciar stese, ma invano.

Nessuno truova: a sé la man ritira; di nuovo tenta, e pur nessuno truova. Di qua l'un braccio, e di là l'altro gira, or l'una o l'altra gamba; e nulla giova. Caccia il sonno il timor; gli occhi apre, e mira: non vede alcuno. Or già non scalda e cova più le vedove piume, ma si getta del letto e fuor del padiglione in fretta: e corre al mar; graffiandosi le gote presaga e certa ormai di sua fortuna. Si straccia i crini, e il petto si percuote, e va guardando (che splendea la luna) se veder cosa, fuor che 'l lito, puote; né, fuor che 'I lito, vede cosa alguna. Bireno chiama: el al nome di Bireno rispondean gli Antri che pietà n'avieno.

Quivi surgea nel lito estremo un sasso, ch'aveano l'onde, col picchiar frequente, cavo e ridutto a guisa d'arco al basso; e stava sopra il mar curvo e pendente. Olimpia in cima vi salí a gran passo (così la facea l'animo possente), e di lontano le gonfiate vele vide fuggir del suo signor crudele: vide lontano, o le parve vedere; che l'aria chiara ancor non era molto. Tutta tremante si lasciò cadere, più bianca e più che nieve fredda in volto; ma poi che di levarsi ebbe potere, al camin de le navi il grido volto, chiamò, quanto potea chiamar più forte, più volte il nome del crudel consorte:

e dove non potea la debil voce supliva il pianto e 'I batter palma a palma. -Dove fuggi, crudel, cosi veloce? Non ha il tuo legno la debita salma. Fa che lievi me ancor: poco gli nuoce che porti il corpo, poi che porta l'alma-. E con le braccia e con le vesti segno fa tuttavia, perché ritorni il legno.

Ma i venti che portavano le vele per l'alto mar di quel giovene infido, portavano anco i prieghi e le querele de l'infelice Olimpia, e 'I pianto e 'I grido; la qual tre volte, a se stessa crudele, per affogarsi si spiccò dal lido; 
pur al fin si levò da mirar l'acque,

e ritornò dove la notte giacque ${ }^{75}$.

No hay demasiadas diferencias entre la Olimpia de Ariosto, la Ariadna de Catulo y la Alcíone de Ovidio. Nótese cómo Olimpia, la primera de estas heroínas, contrasta con Ariadna en que ella sí es gozada y luego traicionada por su amante. Sin embargo, también posee un don que la separa de las otras dos mujeres, al mismo tiempo que la aproxima al peregrino de Góngora: su facilidad para escalar rocas de notable altura («Olimpia in cima vi salí a gran passo»; «la qual tre volte, a se stessa crudele, per affogarsi si spiccò dal lido»). Veamos su reacción después del planto:

Corre di nuovo in su l'estrema sabbia,

e ruota il capo e sparge all'aria il crine;

e sembra forsennata, e ch'adosso abbia non un demonio sol, ma le decine;

o, qual Ecuba, sia conversa in rabbia, vistosi morto Polidoro al fine.

Or si ferma s'un sasso, e guarda il mare; né men d'un vero sasso, un sasso pare ${ }^{76}$.

De nuevo coincide con Ariadna, por lo que atañe a su hermosa desnudez, en la escena en la que Olimpia es rescatada por Orlando, ya en el canto XI:

Poi con gran pianto seguitò, dicendo come lo sposo suo l'avea tradita;

75. Ariosto, Orlando furioso, pp. 320-323, canto X, octavas 20-26: «Atrás quedó la playa, atrás la pobre / Olimpia, que durmió sin saber nada / hasta que el Alba en su dorado carro / dejó el suelo sembrado de rocío / y a la orilla llegaron los lamentos / del ancestral dolor de los Alciones. / Medio dormida aún, tiende su mano / en busca de Bireno, pero en vano. / Nada encuentra, y al punto la retira; / lo intenta una vez más, y nada encuentra. / Tienta con uno y otro brazo, estira / una pierna y la otra..., pero nada. / El temor la despierta: abre los ojos / y no ve a nadie. Ya las viudas plumas / restan sin su calor, / porque ella deja el lecho y el dosel con gran presteza, / y arañándose el rostro, hacia el mar corre / presagiando y temiendo su infortunio. / Se mesa los cabellos, se golpea / el pecho y, alumbrada por la luna, / mira para ver algo más que playa; / pero, salvo la playa, no ve nada. / Llama a Bireno, y a su grito solo / los Antros le responde piadosos. / Se alzaba en un extremo de la playa / un peñasco al que el mar, / con sus envites, / había excavado por debajo en forma / de un gran arco pendiente. Subió Olimpia / a lo alto con paso decidido / (así la espoleaba su denuedo) / y vio a lo lejos las hinchadas velas / de aquel cobarde amado que se ausenta; / lejos las vio o al menos creyó verlas / pues el aire no estaba aún muy claro, / y se dejó caer, estremecida, / más blanca y más helada que la nieve. / Cuando ya tuvo fuerzas para alzarse, / dirigiendo su voz hacia las naves, / llamó gritando a su cruel consorte / y repitió mil veces su vil nombre; I si la voz era débil, la ayudaban / el llanto o las palmadas de sus manos. / - ¿Adónde vas, cruel, con tal premura? / Falta en tu nave la debida carga: / haz que vuelva a por mí, que no le pesa / llevar mi cuerpo, pues me lleva el alma-. / Y agitando las ropas y los brazos / hacía señas convocando al barco. / Pero los mismos vientos que llevaban / hacia alta mar las velas de aquel pérfido, / se llevaban los ruegos, los lamentos, / gritos y llantos de la triste Olimpia, / quien por tres veces se asomó a la roca / intentando tirarse y ahogarse, / mas de mirar las aguas quedó ahíta / y regresó a la tienda en que dormía». Las cursivas tanto en el texto italiano como en la traducción de Micó son mías.

76. Ariosto, Orlando furioso, pp. 324-325, canto X, octava 34: «Corre de nuevo hacia la playa, agita / la cabeza y al viento va esparciendo / su cabellera como poseída / por toda una caterva de demonios, / desquiciada y rabiosa como Hécuba / ante el cadáver de su Polidoro. / Contempla el mar subida en una roca / y se confunde con la misma roca». 
che la lasciò su l'isola dormendo,

donde ella poi fu dai corsar rapita.

E mentre ella parlava, rivolgendo

s'andava in quella guisa che scolpita

o dipinta è Dïana ne la fonte,

che getta l'acqua ad Ateone in fronte;

che, quanto può, nasconde il petto e I'ventre,

più liberal dei fianchi e de le rene.

Brama Orlando ch'in porto il suo legno entre;

che lei, che sciolta avea da le catene,

vorria coprir d'alcuna veste. [...] $]^{77}$

En resumidas cuentas, quisiera haber ampliado aquí una de las tesis del importante libro de Daniel Javitch (Saggi sull'Ariosto e la composizione dell' Orlando Furioso, Lucca, Pacini Fazzi, 2012), para quien «el éxito comercial de las Metamorfosis vertidas por Dolce en el molde de Ariosto, con octava rima, treinta cantos en vez de quince, aperturas y finales de canto similares a las del Furioso, es un indicio [...] de la compatibilidad estética y estructural de los dos poemas» ${ }^{78}$. Y yo diría que de los tres: porque a partir de ahora habría que sumar las Soledades de Góngora.

\section{EL MAR DE CAMOENS}

Como colofón, esta vez lusitano, ¿no tendrá algo que ver en el comienzo y en el métrico llanto de las silvas de don Luis este soneto de su tocayo Camoens?:

Como quando o mar tempestuoso

o marinheiro, lasso e trabalhado,

de un naufragio cruel já salvo a nado, só ouvir falar nele o faz medroso,

e jura que, em que veja bonançoso

o violento mar e sossegado,

não entre nele mais, mas vai forçado

pelo muito interesse cobiçoso;

assi, Senhora, eu, que da tormenta

de vossa vista fujo, por salvar-me,

jurando de não mais em outra ver-me:

minh'alma, que vós nunca se ausenta,

dá-me por preço ver-vos, faz tornar-me

donde fugi tão perto da perder-me ${ }^{79}$.

77. Ariosto, Orlando furioso, pp. 382-383, canto XI, octavas 58-59: «Prosiguió con gran llanto refiriendo / la traición de su esposo en una isla / donde la abandonó mientras dormía, / dejándola a merced de los corsarios. / Mientras hablaba, remedaba Olimpia / el sublime pudor de la esculpida / o pintada Diana que en la fuente / al curioso Acteón moja la frente: / cubre sus pechos y su vientre, y deja / a la vista la espalda y los costados. / Reclama al punto Orlando su navío, / pues la dama, ya libre de cadenas, / necesita cubrirse con ropajes».

78. Cit. por Blanco, 2016, p. 345

79. Camoens, Lírica completa, p. 138. Tocco (2008, pp. 223-224) ha señalado que «es todavía tarea pendiente el cotejo sistemático entre las obras de Góngora, cuya biblioteca sin duda incluía también los textos [camonianos], y el corpus lírico y épico del poeta luso: pero basta con hojear los dos grandes 
Coinciden el «mar tempestuoso», que Góngora convertiría dentro de las Soledades en «montes de agua»; el marinero «extenuado pero fuerte», que don Luis igualó con Ganimedes; el naufragio; el que ambos personajes se salven a nado; el mar, primero «violento» y luego «sosegado»; nada distinto, en suma, de aquel díptico del cordobés en el que reza: «Del Ocëano pues antes sorbido, / y luego vomitado» (vv. 22-23); y claro, la alargada sombra del par de «tormentosas señoras», de las que huían tanto el náufrago de Camoens como «el más misterioso de los héroes errantes»80; el mismo que, por voluntad de don Luis, ceñido esta vez a la escuela cancioneril, durante el «métrico llanto» (1614, vv. 112-189) de la Soledad II imaginó a su dueña como una «enemiga amada».

\section{BIBLIOGRAFÍA}

Alatorre, Antonio, «Notas sobre las Soledades (a propósito de la edición de Robert Jammes», Nueva Revista de Filología Hispánica 1, 1996, pp. 57-97.

Alatorre, Antonio, «De Góngora, Lope y Quevedo», Nueva Revista de Filología Hispánica, XLVIII, 2, 2000, pp. 299-332.

Alonso, Dámaso, Las «Soledades», nuevamente editadas por Dámaso Alonso, Madrid, Cruz y Raya, 1936.

Alonso, Dámaso, «Los hurtos de Estillani y del Chiabrera», en Obras completas. Góngora y el gongorismo, Madrid, Gredos, 1982, pp. 525-539.

Alonso Miguel, Álvaro, «La metamorfosis del cíclope», en Poéticas de la metamorfosis. Tradición clásica, Siglo de Oro y modernidad, coord. Gregorio Cabello y Javier Campos Daroca, Málaga, Universidad de Málaga/Universidad de Almería, 2002, pp. 273-282.

Ariosto, Ludovico, Orlando furioso, trad. José María Micó, Madrid, Espasa, 2005.

Blanco, Mercedes, Góngora heroico. Las «Soledades» y la tradición épica, Madrid, CEEH, 2012.

tomos de Vilanova sobre las fuentes del Polifemo para darse cuenta de cuánto Camoens está presente y vivo en la cadena de múltiples influencias que se ejercieron en el tejido de imágenes y palabras de los versos del poeta andaluz. Los elementos que normalmente se consideran de procedencia camoniana (algunos de los cuales ya aparecen en las primeras apologías de las obras de Góngora) son: el verso inicial de las Soledades, inspirado en el primer verso de la octava 72 del canto II de los Lusíadas; el cierre del soneto "Mientras por competir con tu cabello", que está en deuda con el v. 4 de V, 57; la invectiva del serrano contra las navegaciones y los descubrimientos por oriente de la Soledad primera (vv. 366-504), donde los ecos de las recriminaciones del Velho do Restelo (IV, 94-104) no dejan de ser evidentes». Ver asimismo Entwistle, 1933, y sobre todo Micó, 2015, pp. 122-120. Sorprende que hasta la fecha no se haya relacionado el soneto «Como quando o mar tempestuoso» con las Soledades; ni siquiera lo hizo Carreira en su fino artículo sobre «el mar de Camoens» (2014, p. 81), donde cita solo los cuartetos.

80. Guillén, 1998, p. 68 
Blanco, Mercedes, «Bajo el signo de la agudeza: el arte epigramático de las décimas de Góngora», en Góngora y el epigrama. Estudios sobre las décimas, ed. Juan Matas Caballero, José María Micó y Jesús Ponce Cárdenas, Madrid/Frankfurt am Main, Iberoamericana/Vervuert, 2013, pp. 43-77.

Blanco, Mercedes, «Entre Arcadia y Utopía: el país imaginado de las Soledades de Góngora», Studia Aurea, 8, 2014, pp. 131-175.

Blanco, Mercedes, Góngora o la invención de una lengua, León, Universidad de León, 2016.

Blecua, Alberto, «Virgilio, Góngora y la nueva poesía», en La hidra barroca. Varia lección de Góngora, ed. Rafael Bonilla Cerezo y Giuseppe Mazzocchi, Granada, Junta de Andalucía, 2008, pp. 119-127.

Bonilla Cerezo, Rafael, y Garosi, Linda, «"Con arguta sambuca il fier sembiante": la Polifemeida de Giovan Battista Marino», en La hidra barroca: varia lección de Góngora, ed. Rafael Bonilla Cerezo y Giuseppe Mazzocchi, Granada, UNIA, 2008, pp. 181-218.

Bonilla Cerezo, Rafael, y Tanganelli, Paolo, «Soledades» ilustradas. Retablo emblemático de Góngora, Salamanca, Delirio, 2013.

Bonilla Cerezo, Rafael y Tanganelli, Paolo, «Le Soledades e il carme 64 di Catullo: una prima esplorazione», en Intorno all'epica ispanica, ed. Paola Laskaris y Paolo Pintacuda, Como, Ibis, 2016, pp. 217-255.

Bresadola, Andrea, «Ariosto en la obra poética de Góngora», en La hidra barroca: varia lección de Góngora, ed. Rafael Bonilla Cerezo y Giuseppe Mazzocchi, Granada, UNIA, 2008, pp. 161-172.

Cacho Casal, Rodrigo, «Góngora in Arcadia: Sannazaro and the Pastoral Mode of the Soledades», Romanic Review, 98.4, 2007, pp. 115-135.

Camões, Luis de, Lírica completa, ed. Maria de Lurdes Saraiva, Lisboa, Imprensa Nacional/Casa da Moeda, 1980, 3 vols.

Cancelliere, Enrica, «Estrategias metaliterarias en las Soledades», en Góngora hoy X. «Soledades», ed. Joaquín Roses, Córdoba, Diputación Provincial, 2010, pp. 61-79.

Carreira, Antonio, Gongoremas, Barcelona, Península, 1998.

Carreira, Antonio, «El mar de Camões: camino y palestra», en Aurea poesis. Estudios para Begoña López Bueno, ed. Luis Gómez Canseco, Juan Montero y Pedro Ruiz Pérez, Córdoba/Huelva/Sevilla, Universidad de Córdoba/Universidad de Huelva/Universidad de Sevilla, 2014, pp. 71-86.

Catulo, Poesías, trad. Juan Antonio González Iglesias, Madrid, Cátedra, 2006.

Chevalier, Maxime, Los temas ariostescos en el romancero y en la poesía española del Siglo de Oro, Madrid, Castalia, 1968. 
Cruz Casado, Antonio, «Hacia un nuevo enfoque de las Soledades de Góngora», Revista de Literatura, 52, 1990, pp. 67-100.

Dolfi, Laura, «El mundo metafórico de la Soledad primera: contenidos y finalidades», en La Edad del Genio: España e Italia en tiempos de Góngora, ed. Begoña Capllonch, Sara Pezzini, Giulia Poggi y Jesús Ponce Cárdenas, Pisa, ETS, 2013, pp. 201-218.

Entwistle, William, «Two Set-Pieces in the Soledades», Hispanic Review, I, 1933, pp. 284-289.

Fernández Corte, José Carlos, «Introducción», en Catulo, Poesías, trad. Juan Antonio González Iglesias, Madrid, Cátedra, 2006, pp. 7-181.

Fernández de Córdoba, Francisco (abad de Rute), Examen del «Antídoto» o Apología por las «Soledades» de don Luis de Góngora contra el autor del «Antídoto», ed. crítica Matteo Mancinelli, Córdoba, Almuzara, en prensa.

Ferretti, Francesco, «Peregrini erranti. La Gerusalemme Liberata nelle Soledades», en La Edad del Genio: España e Italia en tiempos de Góngora, ed. Begoña Capllonch, Sara Pezzini, Giulia Poggi y Jesús Ponce Cárdenas, Pisa, ETS, 2013, pp. 253-278.

Góngora, Luis de, Antología poética, ed. Antonio Carreira, Madrid, Castalia Didáctica, 1986 .

Góngora, Luis de, Soledades, ed. John Beverley, Madrid, Cátedra, 1993.

Góngora, Luis de, Soledades, ed. Robert Jammes, Madrid, Castalia, 1994.

Góngora, Luis de, Romances, ed. Antonio Carreira, Barcelona, Quaderns Crema, 1998, 4 vols.

Góngora, Luis de, Le solitudini e altre poesie, ed. y trad. Norbert von Prellwitz, Milano, Rizzoli, 2002.

Góngora, Luis de, Antología poética, ed. Antonio Carreira, Barcelona, Crítica, 2009.

Góngora, Luis de, Fábula de Polifemo y Galatea, ed. Jesús Ponce Cárdenas, Madrid, Cátedra, 2010.

Góngora, Luis de, Poesía, ed. Antonio Carreira, París, Proyecto Polemos, 2016 (<http:// obvil.sorbonne-universite.site/corpus/gongora/gongora_obra-poeticas).

González Ramírez, David, Del taller de imprenta al texto crítico. Recepción y edición de la «Guía y avisos de forasteros» de Liñán y Verdugo, Málaga, Analecta Malacitana, 2011.

Guillén, Claudio, Múltiples moradas. Ensayo de literatura comparada, Barcelona, Tusquets, 1998.

Javitch, Daniel, Saggi sull'Ariosto e la composizione dell' Orlando Furioso, Lucca, Pacini Fazzi, 2012. 
Jones, Royston O., «The Poetic Unity of the Soledades de Góngora», Bulletin of Hispanic Studies, XXXI, 1954, pp. 189-204.

Lara Garrido, José, «Un nuevo encuadre de las Soledades. Esbozo de relectura desde la Económica renacentista», Calíope, IX, 2, 2003, pp. 5-34.

Lara Garrido, José, «El peregrino en su patria de Lope de Vega desde la poética del romance griego», en Lope en 1604, Lleida, Universitat Autónoma de Barcelona (Departament de Filología Espanyola)/Prolope/ Editorial Milenio, 2004, pp. 95-122.

Lara Garrido, José, «Prolegómenos para una relectura desde el Furioso del Romance de Angélica y Medoro de Góngora», en La tela de Ariosto, ed. Paolo Tanganelli, Málaga, Analecta Malacitana, 2009, pp. 51-99.

Lida de Malkiel, María Rosa, «El hilo narrativo de las Soledades», en La tradición clásica en España, Barcelona, Ariel, 1975, pp. 243-251.

López Bueno, Begoña (ed.), El poeta Soledad, Zaragoza, Prensas Universitarias de Zaragoza, 2011.

Martín Morán, José Manuel, «La metamorfosis del mundo en las Soledades. El centauro de la hipálage doble», en Actas del V Congreso de la Asociación Internacional del Siglo de Oro, ed. Christoph Strosetzki, Madrid/Frankfurt am Main, Iberoamericana/Vervuert, 1999, pp. 862-880.

Matas Caballero, Juan, «Las Soledades a la luz de los sonetos de Góngora: la prefiguración del peregrino», en La Edad del Genio: España e Italia en tiempos de Góngora, ed. Begoña Capllonch, Sara Pezzini, Giulia Poggi y Jesús Ponce Cárdenas, Pisa, ETS, 2013, pp. 317-330.

Mazzocchi, Giuseppe, «La biblioteca imaginada del genio», en La hidra barroca. Varia lección de Góngora, ed. Rafael Bonilla Cerezo y Giuseppe Mazzocchi, Granada, Junta de Andalucía, 2008, pp. 55-80.

Méndez, Sigmund, «Sensus mythologicus atque astrologicus: la alegoría del toro celeste de Góngora», Studia Aurea, 6, 2012, pp. 31-98.

Micó, José María, Para entender a Góngora, Barcelona, Acantilado, 2016.

Morreale, Margherita, «El mundo del Cortesano», Revista de Filología Española, XI, 1958-1959, pp. 230-260.

Osuna Cabezas, María José (ed.), Góngora vindicado: «Soledad primera», ilustrada y defendida, Zaragoza, Prensas Universitarias de Zaragoza, 2009.

Ovidio, Las metamorfosis, ed. Juan Francisco Alcina, Barcelona, Planeta, 1990.

Pellicer, José de, Lecciones solemnes a las obras de don Luis de Góngora y Argote, Madrid, Imprenta del Reino, 1630. 
Pérez Lasheras, Antonio, «Góngora y los clásicos», en La hidra barroca. Varia lección de Góngora, ed. Rafael Bonilla Cerezo y Giuseppe Mazzocchi, Granada: Junta de Andalucía, 2008, pp. 129-141.

Poggi, Giulia, «Mi voz por dulce, cuando no por mía: Polifemo entre Góngora y Stigliani», en Góngora hoy (VII). El Polifemo, ed. Joaquín Roses, Córdoba, Diputación Provincial, 2005, pp. 53-74.

Poppenberg, Gerhard, «La Arcadia en la Fábula de Polifemo y Galatea de Góngora», Creneida, 3, 2015, pp. 210-260.

Reyes, Alfonso, «Necesidad de volver a los comentaristas», en Cuestiones gongorinas, incluido en Obras completas. VII, México, Fondo de Cultura Económica, 1958, pp. 146-151.

Rico, Francisco, «El gongorismo de Ovidio», en Primera cuarentena. Tratado general de literatura, Barcelona, Sirmio, 1987, pp. 107-110.

Rojo Vega, Anastasio, «El duque de Béjar, Cervantes y Juan de Navas», en El mecenazgo literario en la casa ducal de Béjar durante la época de Cervantes, ed. José Ignacio Díez Fernández, s. I. [Burgos], Fundación Instituto Castellano y Leonés de la Lengua, 2005, pp. 211-262.

Romanos, Melchora, «Grandeza y miseria de los comentaristas de Góngora en el siglo XVII», en Góngora hoy $(I, I I, I I I)$, ed. Joaquín Roses, Córdoba, Diputación Provincial de Córdoba, 2002, pp. 201-218.

Roses, Joaquín, «Pasos, voces y oídos. El peregrino y el mar en las Soledades de Góngora (II, vv. 112-189)», en Da Góngora a Góngora, ed. Giulia Poggi, Pisa, ETS, 1997, pp. 181-195.

Salcedo Coronel, García de, «Soledades» de don Luis de Góngora comentadas, Madrid, Imprenta Real, 1636.

Sinicropi, Giovanni, Saggio sulle «Soledades» di Góngora, Bologna, Capelli Editore, 1976.

Spitzer, Leo, «La Soledad primera de Góngora. Notas críticas y explicativas a la nueva edición de D. Alonso», en Estilo y estructura en la literatura española, Barcelona, Crítica, 1980, pp. 257-290.

Suárez de Figueroa, Cristóbal, Pusílipo. Ratos de conversación en los que dura en paseo, ed. Jonathan Bradbury, París, Universidad de la Sorbona, 2016 (<http:// obvil.sorbonne-universite.site/corpus/gongora/1629_pusilipo-figueroas).

Tocco, Valeria, «El encomio de Góngora al sin igual tesoro camoniano. Acerca de la canción proemial de Las Lusiadas de Luis de Camões que tradujo Luis Gómez de Tapia, natural de Sevilla (1580)», en La hidra barroca, ed. Rafael Bonilla Cerezo y Giuseppe Mazzocchi, Granada, Junta de Andalucía, 2008, pp. 219-229. 
Trambaioli, Marcella, «El peregrino de amor en Lope y Góngora: entre competición y mecenazgo», en El duque de Medina Sidonia: mecenazgo y renovación estética, dir. José Manuel Rico García y Pedro Ruiz Pérez, Huelva, Universidad de Huelva, 2015, pp. 203-228.

Vázquez Siruela, Martín, Manuscrito BNE, 3893, transc. Raquel Rodríguez Conde y Antonio Valiente Romero, 2017 [recurso digital facilitado por los autores].

Vilanova, Antonio, «El peregrino de amor en las Soledades de Góngora», en Erasmo y Cervantes, Barcelona, Lumen, 1989, pp. 410-455.

Virgilio, Eneida. Volumen I (Libros I-III), trad. y ed. Luis Rivero García, Juan A. Estévez Sola, Myriam Librán Moreno y Antonio Ramírez de Verger, Madrid, CSIC/ Tirant Lo Blanch, 2009.

Virgilio, Eneida. Volumen II (Libros IV-VI), trad. y ed. Luis Rivero García, Juan A. Estévez Sola, Myriam Librán Moreno y Antonio Ramírez de Verger, Madrid, CSIC, 2011. 